\title{
Association of potential celiac disease and refractory iron deficiency anemia in children and adolescents
}

\author{
Mahdi SHAHRIARI ${ }^{1}$, Naser HONAR ${ }^{2}$, Ali YOUSEFI ${ }^{3}$ and Hazhir JAVAHERIZADEH ${ }^{4}$
}

Received 11/7/2017 Accepted 18/9/2017

\begin{abstract}
Background - Celiac disease is an enteropathy caused by dietary gluten. The combination of serologic, genetic and histologic data has led to description of other categories of this disease. Objective - There are a number of patients with iron deficiency anemia (IDA) that do not respond to iron treatment and may be repeated for many times, Therefore, we aimed to investigate celiac disease in this group. Methods - In this cross sectional transverse prospective study from August 2011 to February 2013, in a Pediatric care clinic affiliated to Shiraz University of Medical Sciences, 184 children including 92 IDA patients who responded to treatment using iron supplement, 45 non-responding iron deficient patients, and 47 healthy individuals, with the maximum age of 18 years, with written consent from their parents, participated in serologic screening (with Anti-TTG antibody and anti-Endomysial antibody) for celiac disease. Patients with at least one positive serology test underwent multiple mucosal biopsy from bulb and duodenum. Results - Among 184 participants, 19 (10.3\%) subjects had positive serologic test for celiac disease, including $13(28.9 \%)$ patients in the group with refractory IDA, $5(5.4 \%)$ patients in the group with treated IDA, and 1 patient in the healthy group. The frequency of positive serologic test in the group with IDA resistant to treatment was prominently higher than the other two groups $(P<0.001)$. Among the patients with positive serologic celiac test who underwent endoscopy and biopsy, no histologic evidence of celiac disease was seen. They were diagnosed as potential celiac disease. Conclusion - Frequency of potential celiac disease in patients with refractory IDA was higher than control the subjects. Therefore, we recommend serologic screening for early detection and minimizing the complications of celiac disease and repeated iron therapy for this group.
\end{abstract}

HEADINGS - Celiac disease. Iron deficiency, complications. Iron-deficiency anemia. Serologic tests.

\section{INTRODUCTION}

Celiac disease (CD) is an enteropathy caused by the immune system which is stimulated with dietary gluten in genetically susceptible individuals. Wheat, barley and rye are rich in gluten and may trigger the disease. CD primarily affects the small intestine and progressively causes flattening of its mucosa. CD has different clinical manifestations. CD used to be defined by its classic clinical manifestations such as weight loss, diarrhea, abdominal distention and steatorrhea, but the combination of serologic, genetic and histologic findings has led to description of other categories of CD such as atypical, silent/subclinical, latent and potential ${ }^{(1,2,3)}$. Availability of serologic screening with acceptable sensitivity and specificity will lead to the diagnosis of $\mathrm{CD}$ in patients with minimal clinical symptoms or even asymptomatic individuals. Serologic markers that used for screening of celiac are Anti-transglutaminase antibody (Anti TTG) and Anti Endomysial antibody (EMA) which are sensitive and specific ${ }^{(4,5)}$. $\mathrm{CD}$ has a prevalence rate of 1 percent in general population of Europe and North America; the same prevalence was reported in a small study from $\operatorname{Iran}^{(6)}$.
Iron deficiency anemia (IDA) is the most common nutritional deficiency in children. According to World Health Organization reports, anemia affects 25 percent of the world's population. Preschool children and women are affected more than other groups ${ }^{(7)}$. Iron balance is mainly determined by intestinal absorption and iron transferring mechanism. In children about 30 percent of required iron of the body is provided by diet. Main causes of IDA are chronic blood loss from gastrointestinal system (peptic ulcer, hemorrhoids and parasitic infections) or gynecologic problems (menorrhagia, menometrorrhagia, malignancy, etc.), inadequate intake, increased daily requirement (especially in infancy and pregnancy) and decreased absorption that includes $\mathrm{CD}, H$. pylori infection and autoimmune gastritis. Malabsorption causes should be considered especially in refractory IDA; which is very common in $\mathrm{CD}$ and it can be the only manifestation in subclinical and silent $\mathrm{CD}^{(8,9)}$. In cases of IDA who do not respond to iron supplements, treatment may be repeated for many times and it may cause complications such as discoloration of the teeth, constipation and abdominal pain. The aim of this study was to investigate association of CD in children with refractory IDA to help diagnosis and treatment in this group.

Declared conflict of interest of all authors: none

Disclosure of funding: no funding received

${ }_{1}^{1}$ Pediatric Hematology and Oncology, Shiraz University of Medical Sciences, Shiraz, Iran; ${ }^{2}$ Gastroenterohepatology Research Center, Shiraz University of Medical Sciences, Shiraz, Iran; ${ }^{3}$ Shiraz University of Medical Sciences, Shiraz, Iran; ${ }^{4}$ Research Center for Infectious Diseases of Digestive System [ Alimentary Tract Research Center], Ahvaz Jundishapur University of Medical Sciences, Ahvaz, Iran.

Correspondence: Hazhir Javaherizadeh. Abuzar Children's Hospital, Ahvaz Jundishapur University of Medical Sciences, Ahvaz, Iran. E-mail: hazhirja@yahoo.com 


\section{METHODS}

In a cross sectional transverse prospective study, during August 2011 and February 2013, IDA cases with the maximum age of 18 who were referred to Shiraz University of Medical Science affiliated pediatric hematology clinics (Hb less than normal for their age and ferritin level $<20 \mathrm{ng} / \mathrm{mL}$ ) underwent screening for celiac and treatment with iron supplement with therapeutic dose was started for them. Response to iron therapy was defined by increase of more than $1 \mathrm{gr} / \mathrm{dL}$ of hemoglobin or rise of serum ferritin above $20 \mathrm{ng} / \mathrm{mL}$ (McLean et al., 2009). Exclusion criteria included patients without mentioned response and known cause such as inappropriate dose and timing by parents, intolerance of supplement, recent blood loss (recent parasitic infestation such as giardiasis, cow's milk allergy), etc. After obtaining consent, 184 individuals including 92 patients who responded to treatment with iron, 45 non-responding iron deficient patients, and 47 healthy individuals participated in Serologic screening (with Anti TTG and EMA) for celiac disease (TABLE 1). Upper GI endoscopy and duodenal mucosal biopsy were done for patients who had at least one positive serology test by pediatric gastroenterologist. Marsh classification was used for histological evaluation under supervision of experienced pathologist. The study was approved by ethics committee of research department of Shiraz University of Medical Sciences.

TABLE 1. Characteristics of study groups: there was no significant difference between groups

\begin{tabular}{lcccc}
\hline Study group & $\begin{array}{c}\text { Refractory } \\
\text { IDA }\end{array}$ & $\begin{array}{c}\text { Treated } \\
\text { IDA }\end{array}$ & $\begin{array}{c}\text { Healthy group } \\
\text { (without IDA) }\end{array}$ & Total \\
\hline Number & 45 & 92 & 47 & 184 \\
Age (average) & 5.1 & 5.2 & 5.3 & 5.2 \\
$\begin{array}{l}\text { Gender } \\
\text { (male/female) }\end{array}$ & $1.34: 1$ & $2.2: 1$ & $2.3: 1$ & $1.17: 1$ \\
\hline
\end{tabular}

IDA: iron deficiency anemia.

\section{Antibody test}

Sera from each participant were stored at $-70^{\circ} \mathrm{C}$. IgG anti TTG antibody and EMA assays were measured by enzyme-linked immunosorbent assay (ELISA) (Aida Gmbh, Germany). Cut off values were $18 \mathrm{IU} / \mathrm{mL}$ for anti TTG and 20 for EMA defined by their manufacturers.

\section{Statistical analysis}

Chi-square test was used to compare CD gender and CD prevalence differences between the three groups. The comparisons of mean ages between study groups were done by Kruskal-Wallis test. The statistical analysis was performed using SPSS 11.0 for Windows (SPSS Inc., IL, USA). $P$ values of less than 0.05 were considered statistically significant.

\section{RESULTS}

Age and gender were similar in the study groups as shown in TABLE 1 ( $P=0.94, P=0.28$, respectively). Totally $19(10.3 \%)$ individuals had positive serologic tests for CD, including $13(28.9 \%)$ patients in the group with refractory iron deficiency anemia, 5 $(5.4 \%)$ patients in the group with treated iron deficiency, and 1 patient in the healthy group (TABLE 2, FIGURE 1). The frequency
TABLE 2. Serologic features of study groups

\begin{tabular}{lccc}
\hline Study groups & Positive serology & Negative serology & Total \\
\hline Refractory IDA & $13(28.9 \%) *$ & $32(71.1 \%)$ & 45 \\
Treated IDA & $5(5.4 \%)$ & $87(94.6 \%)$ & 92 \\
Without IDA & $1(2.1 \%)$ & $46(97.9 \%)$ & 47 \\
Total & $19(10.3 \%)$ & $165(89.7 \%)$ & 184 \\
\hline
\end{tabular}

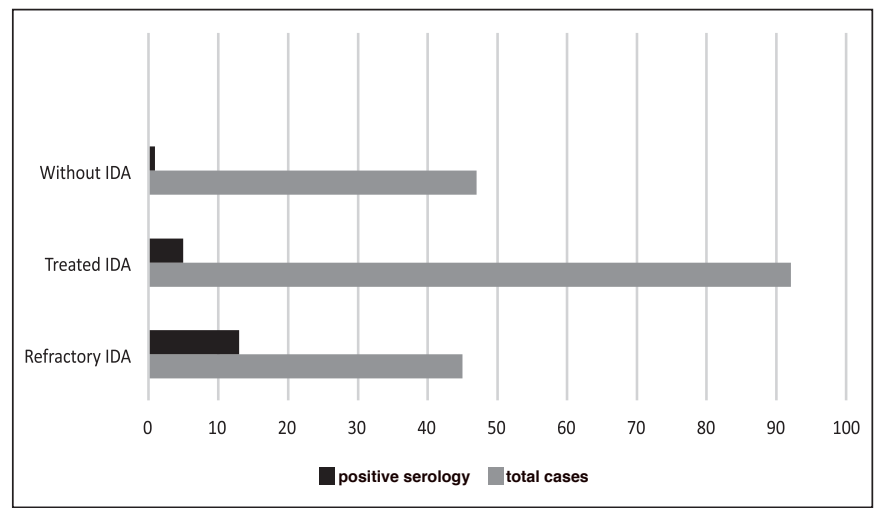

FIGURE 1. Positive serology among different groups of the study. $* P<0.001$. IDA: iron deficiency anemia.

of positive serologic test in the group with iron deficiency resistant to treatment was significantly higher than the other two groups $(P<0.001)$. Among 16 individuals with one positive serologic test, 3 had positive Anti TTG and 13 cases had positive EMA. Three subjects were positive for both Anti TTG and EMA.

Among the subjects with positive serologic celiac test who underwent upper GI endoscopy and duodenal mucosal biopsy; none of them had histologic feature in favor of CD according to Marsh classification. They were diagnosed as patients who may potentially have celiac disease (TABLE 3 ).

TABLE 3. Histologic features among participant according to Marsh classifications

\begin{tabular}{cc}
\hline No of cases & Marsh cassification \\
\hline $\begin{array}{c}\text { Positive serologic findings } \\
(\mathrm{n}=13)\end{array}$ & $\begin{array}{c}\text { No evidence of celiac disease } \\
(\mathrm{n}=13)\end{array}$ \\
\hline
\end{tabular}

\section{DISCUSSION}

CD has different clinical manifestations and with novel diagnostic methods, new subtypes of CD have been described. Typical CD presents with malabsorption while other types may develop metabolic, dermatologic, neurological and other symptoms; however, they may be even asymptomatic. IDA is one of the common clinical manifestations and refractory IDA of unknown origin is one of the high risk groups for CD. In the literature, screening of $\mathrm{CD}$ for this group is recommended. With available and cost-effective serologic screening tests for CD, early diagnosis and treatment in this group will minimize complication of repeated iron therapy and $\mathrm{CD}$. To the best of our knowledge, there is no published study about prevalence of CD in children with refractory IDA in Iran, but the prevalence of celiac disease in children with functional abdominal pain is estimated $1.3 \%$ (nearly 2 times higher than in normal population) in $\operatorname{Iran}^{(10)}$. 
In this study, among 184 participants, $19(10.3 \%)$ subjects had positive serologic test for CD, including $13(28.9 \%)$ patients in the group with refractory iron deficiency anemia, $5(5.4 \%)$ patients in the group with treated iron deficiency, and 1 patient in the healthy group. In Baghbanian et al. study ${ }^{(11)}$, of 402 patients with iron deficiency anemia $10.4 \%$ had positive serology for celiac disease which is similar to our study.

The frequency of positive serologic test in the group with iron deficiency resistant to treatment was prominently higher than the other two groups. Among the patients with positive serologic celiac test who underwent upper GI endoscopy and biopsy from the duodenum, no histologic evidence of celiac disease was seen. These patients which were diagnosed as potential celiac cases needed to be followed and may need re-endoscopy if they develop any symptoms. Prevalence of CD in the healthy group was the same as other studies in Turkey ( $2.1 \%$ vs $1.3 \%)$, which was predictable because of genetic similarities between Iranian and Turkish people ${ }^{(12)}$. In study in the same center on 1500 healthy children participating in serologic screening, $30(2 \%)$ subjects had positive serology for CD.

However, in our study, we had the same frequency rate in the healthy group, and the frequency of potential CD in refractory IDA was significantly higher. In Karaman et al. study, hemoglobin level was significantly lower in cases with iron deficiency anemia and celiac disease compared to children with iron deficiency anemia alone ${ }^{(13)}$.

But in our study, positive serology of celiac disease was seen in $28.3 \%$ and $5.4 \%$ children with refractory IDA and treated IDA. In overall children with treated IDA and refractory IDA, $13.13 \%$ of children had positive serology for celiac disease. In Ertekin et al. study on 61 children aged 2-16 years with iron deficiency anemia, 13 $(21.3 \%)$ had positive serology for celiac disease ${ }^{(14)}$. In Karaman et al. study on 250 children aged 1-16 years with IDA, positive serology was found in $21(8.4 \%)$ of cases $^{(13)}$. Results of our study was similar to Karaman et al. ${ }^{(13)}$ study and lower than Ertekin et al. study ${ }^{(14)}$. This difference may be due to difference in study population.

Frequency of potential CD was about $28 \%$ which was higher than other studies; this could be due to case selection methods, as individuals with IDA who that did not respond to iron treatment were included in this study, while in other studies the cases were IDA of unknown origin or poor iron supplement. In explanation of number of cases with positive serology for CD and patients without histologic features in favor of celiac reasons, factors such as laboratory errors (false positive), inadequate sampling of mucosa, patchy involvement of the duodenum and false negative pathology reports should be considered.

Our Limitations in this study were the lack of HLA testing, single center study, and number of sample size. Another limitation is the lack of longer follow up.

\section{CONCLUSION}

Frequency of typical celiac disease was not higher than the control groups, however, the potential celiac disease had significantly higher prevalence than other groups and as patients with potential CD may progress to typical CD they should be followed. Finally, this study suggests serologic screening for CD in patients with refractory IDA to minimize the complications of $\mathrm{CD}$ and repeated iron treatment.

\section{ACKNOWLEDGEMENT}

This work was done by a grant number 90-01-01-3257 of the Research Affairs of Shiraz University of Medical Sciences, as a thesis of Ali Yousefi in partial fulfillment of requirements for the degree of M.D.

\section{Authors' contributions}

Shahriari M: supervision of the thesis, main idea and data collection. Honar N: data collection and performing endoscopy. Yousefi A: writing proposal, writing the draft of the manuscript and data analysis. Javaherizadeh H: literature search, revision of draft of manuscript, revision of final manuscript and corresponding author.

Shahriari M, Honar N, Yousefi A, Javaherizadeh H. Potencial associação da doença celíaca com anemia ferropriva refratária em crianças e adolescentes. Arq Gastroenterol. 2018;55(1):78-81.

RESUMO - Contexto - A doença celíaca é uma enteropatia causada pelo glúten na dieta. A combinação de dados sorológicos, genéticos e histológicos proporcionou a descrição de outras categorias desta doença. Objetivo - Há pacientes com anemia por deficiência de ferro que não respondem ao tratamento com ferro mesmo que repetido por muitas vezes. O objetivo deste trabalho foi investigar a presença de doença celíaca nestes indivíduos. Métodos - Realizado estudo prospectivo com cruzamento secional transversal, de agosto de 2011 a fevereiro de 2013, em uma clínica de cuidados pediátricos afiliados a Shiraz University Medical Sciences, com 184 crianças incluindo 92 pacientes com anemia por deficiência de ferro que responderam ao tratamento com ferro suplementar, 45 não respondedores e 47 indivíduos sadios, com idade máxima de 18 anos, todos com consentimento informado dos pais. Todos participaram da triagem sorológica (com anticorpos anti-TTG e anticorpo antiendomísio) para doença celíaca. Pacientes com pelo menos um teste de sorologia positiva foram submetidos a biópsia da mucosa múltipla do bulbo e duodeno. Resultados - Entre os 184 participantes, $19(10,3 \%)$ tinham teste sorológico positivo para doença celíaca, incluindo $13(28,9 \%)$ pacientes no grupo com a anemia por deficiência de ferro refratária, $5(5,4 \%)$ pacientes no grupo com anemia por deficiência de ferro tratados e respondedores e 1 paciente do grupo saudável. A frequência de teste sorológico positivo no grupo com anemia por deficiência de ferro resistente ao tratamento foi destacadamente maior do que os outros dois grupos $(P<0,001)$. Entre os pacientes com teste sorológico positivo para doença celíaca submetidos a endoscopia e biópsia, não foi vista nenhuma evidência histológica de doença celíaca. Foram diagnosticados como potencial doença celíaca. Conclusão - Potencial frequência de doença celíaca em pacientes com anemia por deficiência de ferro refratária foi maior do que nos controles. Portanto, recomendamos testes sorológicos de triagem para a detecção precoce, minimizando as complicações da terapia de ferro repetidas para este grupo.

DESCRITORES - Doença celíaca. Deficiência de ferro, complicações. Anemia ferropriva. Testes sorológicos. 


\section{REFERENCES}

1. Admou B, Essaadouni L, Krati K, Zaher K, Sbihi M, Chabaa L, et al. Atypical celiac disease: from recognizing to managing. Gastroenterol Res Pract. 2012;2012:637187.

2. Ensari A. Gluten-sensitive enteropathy (celiac disease): controversies in diagnosis and classification. Arch Pathol Lab Med. 2010;134:826-36.

3. Hill ID, Dirks MH, Liptak GS, Colletti RB, Fasano A, Guandalini S, et al. Guideline for the diagnosis and treatment of celiac disease in children: recommendations of the North American Society for Pediatric Gastroenterology, Hepatology and Nutrition. J Pediatr Gastroenterol Nutr. 2005;40:1-19.

4. Cataldo F, Montalto G. Celiac disease in the developing countries: a new and challenging public health problem. World J Gastroenterol. 2007;13:2153-9.

5. Catassi C, Kryszak D, Louis-Jacques O, Duerksen DR, Hill I, Crowe SE, et al Detection of Celiac disease in primary care: a multicenter case-finding study in North America. Am J Gastroenterol. 2007;102:1454-60.

6. Rostami Nejad M, Rostami K, Emami M, Zali M, Malekzadeh R. Epidemiology of celiac disease in iran: a review. Middle East J Dig Dis. 2011;3:5-12.

7. McLean E, Cogswell M, Egli I, Wojdyla D, de Benoist B. Worldwide prevalence of anaemia, WHO Vitamin and Mineral Nutrition Information System, 19932005. Public Health Nutr. 2009;12:444-54.
8. Brandimarte G, Tursi A, Giorgetti GM. Changing trends in clinical form of celiac disease. Which is now the main form of celiac disease in clinical practice? Minerva Gastroenterol Dietol. 2002;48:121-30.

9. Sharma M, Singh P, Agnihotri A, Das P, Mishra A, Verma AK, et al. Celiac disease: a disease with varied manifestations in adults and adolescents. J Dig Dis. 2013;14:518-25.

10. Farahmand F, Modaresi V, Najafi M, Khodadad A, Moetamed F, Modarres Z. Prevalence of celiac disease in Iranian children with recurrent abdominal pain referred to a pediatric referral center. Iran J Pediatr. 2011;21:33-8

11. Baghbanian M, Farahat A, Vahedian HA, Sheyda E, Zare-Khormizi MR. The prevalence of celiac disease in patients with iron-deficiency anemia in Center and South area of Iran. Arq Gastroenterol. 2015;52:278-82.

12. Uçardă̆ D, Güliter S, Ceneli O, Yakaryilmaz F, Atasoy P, Cağlayan O. Celiac disease prevalence in patients with iron deficiency anemia of obscure origin. Turk J Gastroenterol. 2009;20:266-70.

13. Karaman K, Akbayram S, Kar S, Demirören K. Prevalence of Celiac Disease in Children With Iron Deficiency Anemia in Van Lake Region of Turkey. J Pediatr Hematol Oncol. 2016;38:143-6.

14. Ertekin V, Tozun MS, Kucuk N. The prevalence of celiac disease in children with iron-deficiency anemia. Turk J Gastroenterol. 2013;24:334-8. 